OPEN ACCESS

Edited by:

Mariana Benítez,

National Autonomous University of

Mexico, Mexico

Reviewed by:

Suprasanna Penna,

Bhabha Atomic Research Centre

(BARC), India

Luis F. Goulao,

University of Lisbon, Portugal

Francisca Acevedo,

National Commission for the Knowledge and Use of Biodiversity

(CONABIO), Mexico

*Correspondence:

Ronnie Vernooy

r.vernooy@cgiar.org

Specialty section:

This article was submitted to Agroecology and Ecosystem Services,

a section of the journal

Frontiers in Sustainable Food Systems

Received: 17 November 2020 Accepted: 16 March 2021

Published: 29 April 2021

Citation:

Song $X, L i G$, Vernooy $R$ and Song $Y$ (2021) Community Seed Banks in China: Achievements, Challenges and

Prospects.

Front. Sustain. Food Syst. 5:630400. doi: 10.3389/fsufs. 2021.630400

\section{Community Seed Banks in China: Achievements, Challenges and Prospects}

\author{
Xin Song ${ }^{1}$, Guanqi $\mathrm{Li}^{1}$, Ronnie Vernooy ${ }^{2 *}$ and Yiching Song ${ }^{3}$ \\ ${ }^{1}$ Farmers' Seed Network in China, Nanning, China, ${ }^{2}$ The Alliance of Bioversity International and CIAT, Wageningen, \\ Netherlands, ${ }^{3}$ Center for Chinese Agricultural Policy, Chinese Academy of Sciences, Beijing, China
}

The rich agrobiodiversity of China is under unprecedented threat, experiencing a dramatic loss of many valuable local varieties and wild relatives of main crops. The country's formal conservation system of ex situ genebanks faces serious challenges to address this loss. Community seed banks can play a key role to complement the conservation activities of these genebanks and provide other important collective goods, such as evolutionary services, but although they have been around for some 35 years in various parts of the world, in China they have a much shorter history. In recent years though the number has increased to almost 30 in 2020, in particular due to the efforts of the China Farmers' Seed Network. The community seed banks in the country are very diverse in terms of functions and services, forms of management and institutional linkages. Compared to the most common functions of community seed banks in other countries, China is bringing an important design innovation through two new functions: adding value to seed and produce through innovative marketing strategies, and building regional and national seed system linkages and fostering collaboration. The review of community seed banking not only provides rich empirical evidence, but also makes an important contribution to theory. Building on the achievements of community seed banking in the last decade, there is scope to scale this kind of very valuable agrobiodiversity conservation approach through more effective uptake and support by relevant national policies.

Keywords: China, genebank, community seed bank, conservation, crop diversity, resilient seed system

\section{INTRODUCTION}

Although China is experiencing a rapid and massive urbanization process, it is still a country with 260 million smallholder farmers (97\% of all farming households), with an average landholding of 0.6 ha (National Bureau of Statistics [NBS], 2017). Livelihood conditions differ considerably across the country. The rural areas and smallholder farmers in the west and southwest are the most important targets of the policies concerning national poverty alleviation. These rural areas share common characteristics, such as fragile (mountain) ecologies, highly climate sensitive and weak adaptive capacities. In recent decades, farming systems here have suffered from the loss of agrobiodiversity as local crops and varieties are replaced by modern cultivars (Li et al., 2012; Vernooy et al., 2013; Song et al., 2019). A recent study of the impact assessment of China's Seed Policy by the Chinese Academy of Sciences (CAS) concluded that the rapid socioeconomic changes and transition to modern agriculture have had major negative impacts on farmers' seed systems and livelihood resilience (Center for Chinese Agricultrual Policy [CCAP]., 2018, 
Farmers' Seed Network 2019). As agrobiodiversity can play an important function in climate change adaptation, smallholder farming is under stress, particular affecting women, who play key roles in agriculture due to high levels of male migration to urban areas. The erosion of farmer seed systems and lack of safe and good quality seeds are causing fundamental constraints and hindering the viable development of local initiatives toward food and nutrition security (Subedi and Vernooy, 2019) and sustainable development more broadly (Intergovernmental Science-Policy Platform on Biodiversity Ecosystem Services [IPBES]., 2019). Such development includes the production and consumption of safe, healthy and diversified foods, for which the national demand is increasing due to a series of food safety problems and growing environmental concerns.

China's rich agrobiodiversity is under unprecedented threat, with dramatic loss of many valuable local varieties selected and nurtured for centuries and wild relatives of main crops facing the threat of extinction (Food Agricultural Organization of the United Nations [FAO]., 2008; Li et al., 2009; He et al., 2010; Gao et al., 2011; Xinhua News, 2018). In 2015, the Seeds Administration Bureau of the Ministry of Agriculture launched the third national crop germplasm resource survey and collection. The 2018 preliminary statistics indicated that there were 11,590 grain crops varieties planted in China in 1956 , but only 3,271 varieties remained in 2014, representing a loss rate of $71.8 \%$ (Xinhua News, 2018). In order to control the sharp decrease in crop variety diversity and quantity of agricultural germplasm resources, the Ministry of Agriculture has invested in a "Seed Project" for enlarging the national genebank conservation facilities. By December 2018, the total number of basic collections at the national long-term genebank had reached 502,173 accessions (Xinhua News, 2019). The national conservation system for plant genetic resources includes one national long-term genebank, one national duplication genebank, 10 national medium-term genebanks and 43 national germplasm nurseries and a few in situ protected sites for wild crop relatives managed by the formal system.

The General Office of the State Council of China released a circular on 11 February 2020, outlining requirements to improve the conservation and utilization of agricultural germplasm resources (The State Council of The People's Republic of China, 2020). This is the first policy in China that focuses on the conservation and utilization of agricultural germplasm resources and therefore of great significance. In response to the circular, the Ministry of Agriculture and Rural Affairs pointed out that, "many ancient local varieties and endemic resources are sustained and adapted in people's home gardens, fields and remote mountains and forests." Therefore, according to the ministry, the protection of agricultural germplasm resources "requires the broad participation and support of the whole society... It is necessary to involve more farmers, social organizations in resource conservation." (Ministry of Agriculture Rural Affairs,

Abbreviations: China-NIAHS, China-National Important Agricultural Heritage System; FFS, farmer field school; FSN, Farmers' Seed Network; GIAHS, Globally Important Agricultural Heritage System; PPB, participatory plant breeding; PVS, participatory variety selection.
2020). The reality is that, apart from the formal genebank system, there already exists a country-wide "seed system" for the in situ conservation and sustainable use of agrobiodiversity: it is made up by the 260 million smallholder farmers living in 691,510 villages (National Bureau of Statistics [NBS], 2017). These smallholder farmers are not only seed savers, but also provide very important evolutionary services, which are a public good and upon which plant breeding depends (Bellon et al., 2018). Onfarm and in-situ conservation and utilization are closely linked to local farmers' everyday life and embedded in their traditional farming and knowledge systems in an evolutionary process, which has been going on for thousands of year of farming in China (Zhu, 2010). However, this community-based, farmer seed system has largely remained unrecognized and unsupported by the formal system.

In farmers' seed systems globally, including China, 60-90\% of the seeds on which smallholder farmers depend on is saved on-farm or obtained through local distribution channels, such as exchanges between farmers, intra- and inter-community sharing systems, agro-dealers and local markets. Increasingly, the community seed bank is an important form of organization for on-farm conservation, access and utilization of agricultural germplasm resources (Vernooy et al., 2018, 2019a). A community seed bank is defined as a locally governed and managed institution whose core function is to maintain seeds for local use (Development Fund, 2011). For more than 35 years, community seed banks have conserved, restored, revitalized, strengthened and improved the management of plant genetic resources, in particular, but not solely, of local varieties of crops (Vernooy et al., 2015). Seeds are stored in a shared facility for short duration (usually 1-3 years) and then regenerated by members of the community seed bank collectively (e.g., on a parcel of land belonging to the community seed bank) or individually. Beyond this core conservation function, community seed banks have a broad range of additional purposes and vary significantly in scope, size, governance and management models, infrastructure and technical aspects.

Although community seed banks have been around for some 35 years in various parts of the world (Andersen et al., 2018; Joshi et al., 2018; Vernooy et al., 2019b; Porcuna-Ferrer et al., 2020; Shrestha et al., 2020), in China they have a shorter history, but in recent years the number has increased to almost 30 in 2020. The roles and functions of community seed banks are crucial for the sustainability of farming communities' livelihoods and the State's food security and the building of long term resilient food systems, yet the formal system has followed a heavily top-down modernization approach (including for research and extension), which has neglected the roles of smallholder farmers and their traditional practices. The national genebank system has not yet actively collaborated with community seed banks and accessions from community seed banks have yet to be incorporated in the national genebank system. However, the growing realization of the key roles of indigenous communities in conserving their local species and traditional culture and related knowledge, and civil society's and consumers' needs for healthy, diversified and local specific foods, have created spaces for local crops and seeds. These are the major reasons and drivers for the rapid growth 
of community seed banks in China. However, they have not yet received much scientific and policy attention. This article, as far as we know the first about community seed banks in China, aims to fill this gap.

Based on original participatory action research in various communities in different agroecologies of the country, we briefly review the development and current state of 27 community seed banks in China. This empirical review serves to critically assess and revise the most recent analytical framework for the study of community seed banks developed by Vernooy et al. (2014, 2015). The methodology used for the field research included focus group discussions $(N=22)$ with female and male farmer members of the community seed banks, interviews with female and male key informants (lead seed custodian members of community seed banks) $(N=14)$, a seed questionnaire for members of the community seed banks ( $N=470,306$ women and 164 men), participant observation and collaborative analysis and action planning with farmers and their communities, and case studies (based on the information obtained through the other methods). More details about the methods, including the guide used for the seed questionnaire and the case studies, are provided as Supplementary Material. We then present a revised analytical framework adapted to the Chinese context by expanding the three core functions of community seed banks to five and adding additional services to the three original functions. The validity of the revised framework is illustrated by three cases of community seed banks from three different agroecological regions in Southwest, North, and East China. The three cases selected represent the three major farming types/models that can be identified in three major agro-ecological regions in China: the traditional/indigenous system in the South-west (represented by the Guzhai case), the community-supported agroecological farming system in the East (represented by the Kunshan Organic Farm case) and the conventional agricultural system in the North (represented by the Wang Jinchuang case). The articles conclude by outlining constraints and opportunities of community seed bank development in China.

\section{THE COMMUNITY SEED BANK FUNCTIONS AND SERVICES CONCEPTUAL FRAMEWORK}

For our theoretical review, we used the conceptual community seed bank framework developed by Vernooy et al. (2014, 2015), which was based on a review of the literature up to then and on own experiences of book contributors and insights gained from direct involvement with community seed banks in a number of countries around the world. The framework describes community seed banks from the point of view of their functions and services. This framework is not only useful for carrying out systematic and comprehensive analyses of existing initiatives, but it can also guide the establishment of new community seed banks and inform the development or revision of national policies or strategies to support community seed banks. The framework identifies three core functions of community seed banks (Table 1): (1) conserving plant genetic resources; (2)
TABLE 1 | Multiple functions and services of community seed banks.

\begin{tabular}{|c|c|}
\hline Function & Services \\
\hline Conservation & $\begin{array}{l}\text { - Short-term conservation of mostly local varieties } \\
\text { - Longer-term conservation of heirloom and rare varieties } \\
\text { - Restoration of "lost" varieties } \\
\text { - Development of protocols for conservation of healthy } \\
\text { seed and training of local communities }\end{array}$ \\
\hline $\begin{array}{l}\text { Access and } \\
\text { availability }\end{array}$ & $\begin{array}{l}\text { - Platform offering multiple channels of access and } \\
\text { - Maailability of seeds at the community level } \\
\text { - } \text { Maintenance of locally adapted seed at a low cost } \\
\text { levels } \\
\text { - Access to novel diversity not conserved locally } \\
\text { - Provision of adapted seed to marginal communities not } \\
\text { - } \text { - Wher by commercial seed dissemination efforts } \\
\text { crises/disasters/ acute shortages of seeds } \\
\text { - Seed multiplication including varieties bred through } \\
\text { participatory activities }\end{array}$ \\
\hline $\begin{array}{l}\text { Seed and food } \\
\text { sovereignty }\end{array}$ & $\begin{array}{l}\text { - Maintenance of local control over seed conservation, } \\
\text { exchange and production activities (community-based } \\
\text { biodiversity management) } \\
\text { - Income generation through the sales of seeds } \\
\text { - Sharing of agricultural biodiversity knowledge and } \\
\text { expertise } \\
\text { - Links between in situ and ex situ conservation } \\
\text { - Support of traditional and ethnic food culture and } \\
\text { cultural use } \\
\text { - Contribution to ecological agriculture and food } \\
\text { sovereignty movements }\end{array}$ \\
\hline
\end{tabular}

Source: Vernooy et al. (2014).

enhancing access to and availability of local crop diversity; (3) and ensuring seed and food sovereignty. For each function, a number of services are identified; not all of which are necessarily present at the same time in every community seed bank. Conceptually, the three core functions are connected, complementary and not mutually exclusive.

Community seed banks can also contribute to the adaptive capacity of farmers and communities (in particular with regard to climate change) (McGuire and Sperling, 2013; Mijatović et al., 2013), through a number of strategies: conservation of a portfolio of diverse seeds of crops and crop varieties; conservation of seeds from plants that have high capacity to survive under extreme weather conditions; restoration of "lost" varieties with particular good adaptation potential; accessing novel diversity not conserved locally, and accessing seeds from areas where plants have adapted to extreme weather conditions (Vernooy et al., 2017).

It is to note that, although usually local in nature, a community seed bank can have a multiplier effect if its members cultivate partnerships and engage in networking with multiple actors and share information and seeds with others in the seed sector. Small community seed banks can, thus, sometimes become larger ones; or a network of small community seed banks with considerable scope and depth can emerge, with each one responding to particular needs and interests. Community seed banks can also join forces by establishing a secondary level type 
of organization, such as the national association of community seed banks in Nepal. Community seed banks have flourished and grown around the world for more than three decades with China "joining" in the past decade.

We tested the utility of the original conceptual framework in the context of China through an in-depth review of the operations of 12 of the 27 community seed banks in the country (those directly supported by the Farmers' Seed Network). Before presenting the results of this review, we briefly describe the history of community seed banks in China.

\section{EVOLUTION OF COMMUNITY SEED BANKING IN CHINA}

Seed saving by smallholder households has been an important part of Chinese traditional farming culture for thousands of years (Song, 1998). The long history of collecting, conserving, exchanging, and managing local varieties on an individual and family basis has made a significant contribution to safeguarding and perpetuating seed diversity and security (Song and Vernooy, 2010). This long and rich agro-cultural trajectory has inspired the formal establishment of community seed banks, which was initiated by research institutions and social organizations a decade ago. According to our field research, there are now 27 community seed banks in China. Nineteen community seed banks are distributed in the Southwest provinces of Yunnan, Guizhou, and Guangxi, with Guangxi having the highest number of 10 (Figure 1).

The first formally established community seed bank was the Xiding Crop Germplasm Resource Bank, established in Xiding township, Menghai county, Xishuangbanna prefecture of Yunnan province, in 2010. This local genebank was established with the main goals of conserving local crop varieties, organizing local farmers, mainly Blang people, to exchange them (mainly of rice and maize) and to showcase the crop diversity in Xiding. The Xiding genebank was supported by the Xiding Township Government, Xishuangbanna Academy of Agricultural Sciences and Bioversity International. Agencies and farmers participated in formulating rules and regulations of the genebank (Yang et al., 2015). In the same period as the establishment of the Xiding genebank, Professor Yunyue Wang at the Yunnan Agricultural University started to work on the conservation and utilization of traditional rice varieties in the Hani terraces in Yuanyang, Yunnan Province. She supported local Hani villagers to collect local traditional rice varieties and build seed banks based on scientific research (Li et al., 2009).

Significant changes started in August 2015, when staff of the Farmers' Seed Network (FSN) visited the Xiding gene bank to meet with local farmers and agro-extensionists to learn from their operational experiences. They returned home inspired by functioning and community-based management of the local genebank. The Farmers' Seed Network was founded in 2013, established on the basis of the participatory action research of the Center for Chinese Agricultural Policy (CCAP) of the Chinese Academy of Sciences and the Maize Research Institute of the Guangxi (GMRI) Academy of
Agricultural Sciences in the Southwest of China. The FSN brings together over 30 communities as action pilots and living labs from 10 provinces across China and works closely with CCAP and the United Nations Environment Programme-International Ecosystem Management Partnership (UNEP-IEMP) of CAS, GMRI, Institute of Crop Science of the Chinese Academy of Agricultural Sciences (ICS-CAAS), China Agricultural University, Yunnan Agricultural University, Kumming Institute of Botany (KIB) and some civil society organizations, such as the Beijing Farmer Market and the China Community-Supported Agriculture coalition. The FSN aims to enhance the farmer seed system through community-based participatory action and capacity building and by linking the formal system and civil society for collaboration and support. In November 2015, the Farmers' Seed Network participated in an international workshop on community seed banks organized by Bioversity International in New Delhi, India, and thereafter, integrated community seed banks into FSN's action agenda.

In May 2016, the first community seed bank supported by the Farmers' Seed Network was established in Stone village, a Naxi village in Lijiang City, Yunnan Province. The seed bank has its roots in the participatory plant breeding trials initiated in the village in 2013 by CCAP and partners. There are 109 varieties collected and documented in the community seed registry, managed by a women group. In 2017, two more FSNsupported community seed banks were established in Yuefeng Island Organic Farm in Kunshan, Jiangsu province, and Sancha village in Heng County, Guangxi province. Both seed banks are located in communities that have more than a decade of organic rice farming history. The two community seed banks provide high quality seed for local organic agriculture. Figure 2 presents the growth of community seed banks over time. In 2020, there were 27 community seed banks across the country.

In 2018, with the support of Oxfam Hong Kong, the Farmers' Seed Network launched a Community Seed Bank Knowledge Dissemination and Action Research Project. In this project, FSN translated to Chinese and published the books Community Seed banks: origins, evolution and prospects (Vernooy et al., 2015) and How to Develop and Manage Your Own Community Seed Bank: Farmers' Handbook (Vernooy et al., 2020a,b,c). These two books provide facilitators and farmers a practical resource about community seed banks at both research and action levels. The project also supported three new community seed banks in Guzhai, Qunan, and Gengdan villages in Guangxi province. A regional network of four community seed banks, encircling Nanning city, was formed to facilitate seed, technology and knowledge exchange with the Guangxi Academy of Agricultural Sciences.

In 2019, the participatory action research in the Stone village extended to Wumu, Youmi, and Labo villages in the same Jinshan river valley, forming a seed network of four Naxi-Moso villages. Inspired by the Stone village seed bank, Wumu, and Labo villages set up their own seed banks. The Stone village seed bank also incubated a branch in Muniuke, a nearby natural village. Managed by a women farmer breeder and her sister group, this seed branch focuses on the conservation, access and dissemination of participatory variety selection trial results. 


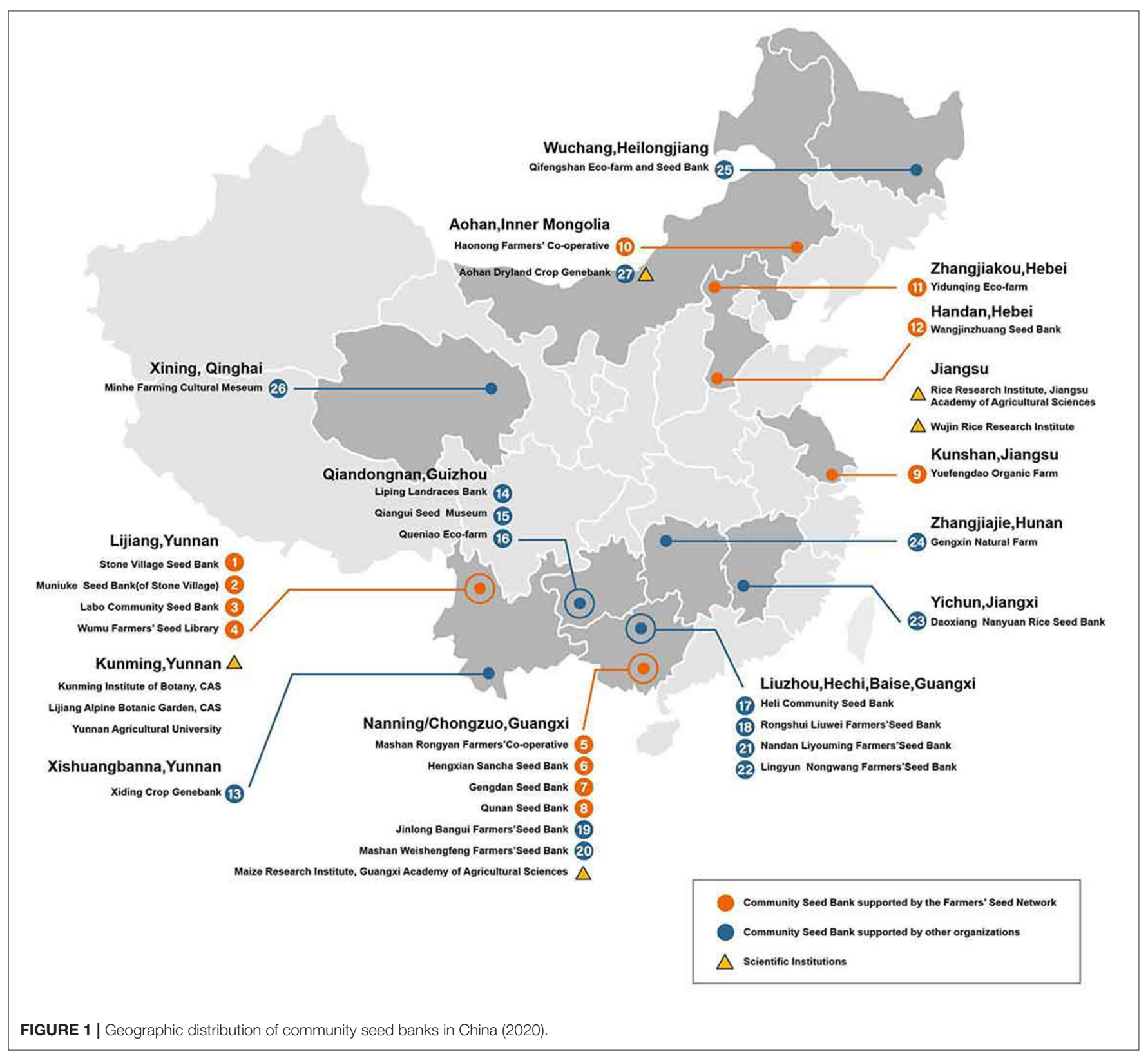

In addition, Partnerships for Community Development (PCD) in Hong Kong has supported smallholder farmers in Yunnan, Guizhou, Guangxi and Sichuan provinces to carry out seed conservation activities and supported scholars to conduct research on the conservation, access and benefit-sharing of agrobiodiversity. With the support of PCD, Guangxi Green Ground Rural Poverty Alleviation and Development Center established the Guangxi Local Variety Conservation Network, aiming to support the establishment of six community seed banks and organize farmers to exchange seeds and associated knowledge.
Experience has shown that community seed banks have the potential for both vertical and horizontal extension. In recent years, Globally Important Agricultural Heritage Systems (GIAHS), Nationally Important Agricultural Heritage Systems (NIAHS) and ecological agriculture are the important strategies for rural development in China. Community seed banks emphasize farmer-led, active conservation and utilization, and local adaptation, which are all central to these strategies. In 2019, the Farmers' Seed Network supported two new seed banks at a GIHAS site, the Aohan dryland farming system in Inner Mongolia, and one in a NIAHS site, Wangjinzhuang of Hebei province. 


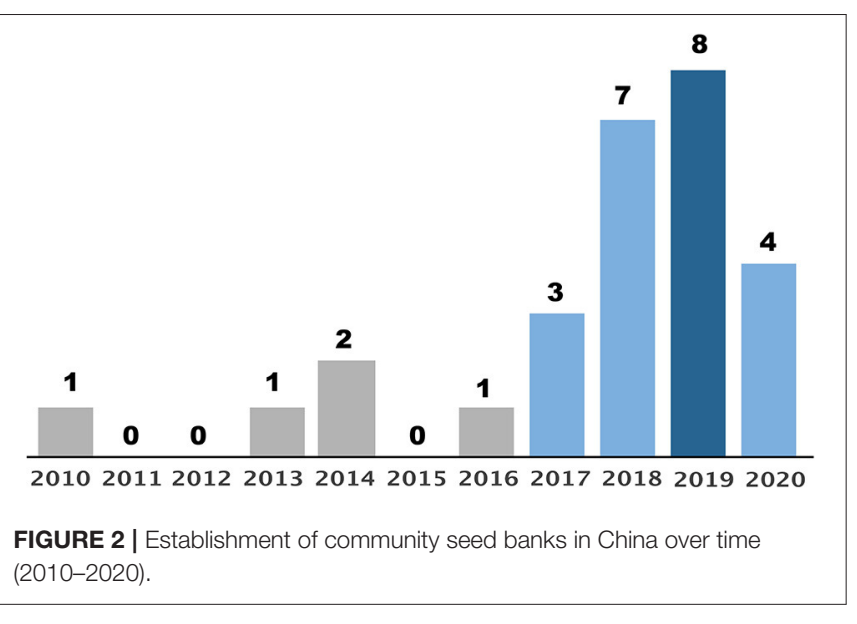

\section{RESULTS: COMMUNITY SEED BANKS THE CHINESE WAY}

Table 2 presents the main functions and services of the 12 community seed banks in China supported by the Farmers' Seed Network. As can be deducted from Table 2, we found that the original conceptual community seed bank framework (Vernooy et al., 2014, 2015) is certainly useful for an analysis of Chinese community seed banks, but has several limitations in the Chinese context. The first limitation: the three major functions and related services are certainly relevant, but not sufficient: we identified two additional functions. The second limitation: the descriptions of the functions could be slightly modified by adding utilization to access and availability; and by renaming seed and food sovereignty to sharing and networking, which broadens the scope of the function while deemphasizing the policy dimension, which in China (but also in other countries) has very limited applicability.

The two new functions are: adding value to seed and produce, and building seed systems linkages and fostering collaboration. Under adding value are services such as contributing to ecological agriculture (9 of 12 community seed banks surveyed) and participating in community-supported agriculture (8 of 12). Under linkages and collaboration, services include linking in situ and ex situ conservation (4 of 12), repatriation via participatory crop improvement (6 of 12) and linking with national and regional genebanks for exchange of seed and knowledge (5 of 12). The second shortcoming is that we identified additional services that relate to the three functions of the original conceptual framework. Under conservation, farmers' field schools and diversity blocks (8 of 12), work on (semi) wild local food and medicinal plants ( 7 of 12) and traditional and ethnic food culture (10 of 12) are important services. Under access and availability, utilization of local food plants for improving nutrition through participatory ecological plant breeding is important (5 of 12). Under sharing and networking important services are fostering of seed exchanges at local and supra-local levels (11 of 12) and networking among communities and with other seed system actors (11 of 12). Table 3 presents links of community seed banks with scientific institutions. All the new elements of the revised framework are summarized in Table 4. These two new functions and related services represent important new dimensions of community seed banking, connecting to and situating seed banks in the larger agro-economy and China's formal institutional system of conservation and sustainable use of agrobiodiversity. This is an empirical novelty that has not yet been observed in other countries or at least, not so clearly. To illustrate the new conceptual framework of community seed banks in more detail, in particular highlighting the new functions and services, we present three cases, one from each of the three major agroecological regions of the country. The case studies resulted from the field research carried out during 2019-2020.

\section{Case 1. Guzhai: the Multi-Functionality of a Women-Led Cooperative and Community Seed Bank in South-West China}

The first case study, Guzhai village in Guangxi (Southwest region), encompasses all five functions and almost all the related services. The work in Guzhai initiated with conservation through participatory plant breeding. Guzhai farmers were encouraged and supported to conserve and utilize their genetic and cultural heritage, such as crop landraces, wild medicinal plants and local livestock varieties. Value adding with partnership building and setting up local market-based channels have been an important function throughout the community seed bank development process. The long-standing partnership with CCAP and GMRI facilitated the farmer and formal seed systems linkages and collaboration.

Guzhai is located in the Karst mountains with rocky terrain and limited arable land. In September 2001, a group of women farmers from the village joined the Participatory Action Research program initiated by the Center for Chinese Agricultural Policy (CCAP). From 2000 to 2004, the program focused on participatory plant breeding, community-based natural resource management and biodiversity enhancement. Initially, the women group leader gathered women around folk music and dance. Since 2004, the program started working on farmers' livelihood security and policy changes through value adding and marketing of local resources and related knowledge.

In 2008, the Guzhai community started to collaborate with a local NGO, Farmers' Friend, which works toward connecting food producers and consumers on a friendship basis and with respect for sustainability. Based on this collaboration emerged the home-based pig-biogas-vegetablemaize-pig circular farming model. In addition, formerly abandoned maize-soybean-pumpkin-sweet potato intercropping practices were re-introduced. The wide adoption of eco-circular methods improved the local environment and led to the direct supply of vegetables to an organic restaurant in Nanning City. Between 2001 and 2011, the CCAP team invited more than 30 national and international agro-ecological experts to visit Guzhai and coordinated knowledge exchanges and seed fairs to promote the recognition of the genetic and cultural values of farmer varieties and their utilization through participatory plant breeding (PPB) and participatory variety selection (PVS) (Vernooy, 2003) and agro-ecological farming practices. 
TABLE 2 | Main functions and services of community seed banks in China supported by the Farmers' Seed Network $(n=12)$.

\begin{tabular}{|c|c|c|c|c|c|c|c|c|c|c|c|c|}
\hline \multirow[t]{2}{*}{ Functions and services } & \multicolumn{4}{|c|}{ Yunnan } & \multicolumn{4}{|c|}{ Guangxi } & \multirow{2}{*}{$\frac{\text { Jiangsu }}{\text { Yuefengdao }}$} & \multirow{2}{*}{$\frac{\text { Inner Mongolia }}{\text { Henggouzi }}$} & \multicolumn{2}{|c|}{ Hebei } \\
\hline & Stone village & Muniuke & Labo & Wumu & Guzhai & Sancha & Gengdan & Qunan & & & Yidunqing & Wangjinzhuang \\
\hline
\end{tabular}

\section{Conservation}

Community registry of local varieties

Short-term conservation of mostly local

varieties

Longer-term conservation of local heirloom/rare

varieties

Restoration of "lost" varieties

Farmers' field school and diversity block

Conservation/domestication of wild/semi-wild

local food and medicinal plants

Support of traditional and ethnic food culture

Access and availability

Maintenance of locally adapted seed at low cost

Access to novel diversity not conserved locally

PPB/PVS seed multiplication

Eco-PB of local food plants for nutrition

\section{Sharing and networking}

Fostering of seed exchanges at local and supra-local levels

Organization of seed fairs and food culture fairs

Sharing of conservation, PPB/PVS methods

and related TK and culture

Networking of communities and with other

seed actors

\section{Adding value to seeds and produce}

Contribution to ecological agriculture

Contribution to CSA model for rural-urban

interaction

Farmer seed enterprise

Geographical indication products and

eco-tourism

\section{Seed system linkages and collaboration}

Enhancement of in-situ and ex-situ linkages

Repatriation via PPB/PVS \& EPB for local food

system

Interaction with provincial or national

genebanks

Integration with GIHAS for biodiversity

$x$

enhancement

Development of protocols of benefit-sharing

mechanism

TK, traditional knowledge; CSA, community-supported agriculture; ECo-PB (EPB), ecological plant breeding; PPB, participatory plant breeding; PVS, participatory variety selection. 
TABLE 3 | Organizational links of community seedbanks.

\begin{tabular}{|c|c|c|c|}
\hline Region & Institute & Crop & Activity \\
\hline \multirow[t]{4}{*}{ Southwest } & $\begin{array}{l}\text { Kunming Institute of Botany, CAS } \\
\text { Lijiang Alpine Botanic Garden, CAS }\end{array}$ & Mountainous wild plants, herbs, turnip & $\begin{array}{l}\text { Participatory variety selection, Farmers' Field } \\
\text { School }\end{array}$ \\
\hline & Yunnan Agricultural University & Rice & \\
\hline & $\begin{array}{l}\text { Maize Research Institute, Guangxi Academy of } \\
\text { Agricultural Sciences }\end{array}$ & Maize & $\begin{array}{l}\text { Participatory plant breeding, Small-scale seed } \\
\text { production, Ecological Farming }\end{array}$ \\
\hline & $\begin{array}{l}\text { Rice Research Institute, Guangxi Academy of } \\
\text { Agricultural Sciences }\end{array}$ & Rice, Soybean & \\
\hline East & $\begin{array}{l}\text { Rice Research Institute, Jiangsu Academy of } \\
\text { Agricultural Sciences } \\
\text { Wujin Rice Research Institute }\end{array}$ & Rice & Ecological Farming, Ecological Plant Breeding \\
\hline North & Aohan Dryland Crop Genebank & Millet & $\begin{array}{l}\text { Geographical Identification product } \\
\text { development, Commercial plant breeding, } \\
\text { Ecological farming }\end{array}$ \\
\hline
\end{tabular}

TABLE 4 | New functions and services of community seed banks in China.

\begin{tabular}{|c|c|}
\hline Function & Services \\
\hline Conservation & $\begin{array}{l}\text { - Farmers' field school and diversity block } \\
\text { - Conservation and domestication of wild/semi-wild local food and medicine plants } \\
\text { - Support of traditional and ethnic food culture }\end{array}$ \\
\hline Access, availability and utilization & $\begin{array}{l}\text { - Utilization of local food plants for improving nutrition through participatory ecological plant } \\
\text { breeding }\end{array}$ \\
\hline Sharing and networking & $\begin{array}{l}\text { - Fostering of seed exchanges at local and supra-local levels } \\
\text { - Organization of seed fairs and food culture fairs } \\
\text { - Sharing of conservation, participatory crop improvement methods and related traditional } \\
\text { knowledge and culture } \\
\text { - Networking among communities and with other seed system actors }\end{array}$ \\
\hline Value adding & $\begin{array}{l}\text { - Contribution to ecological agriculture } \\
\text { - Contribution to Community-Supported Agriculture for rural-urban interaction and the solidarity } \\
\text { - Farmerny } \\
\text { - Promotion and development of Geographical Indication products and eco-tourism }\end{array}$ \\
\hline Seed systems linkages and collaboration & $\begin{array}{l}\text { - Enhancing in situ and ex situ linkages } \\
\text { - Repatriation via participatory crop improvement for improving local food systems } \\
\text { - Interaction with provincial or national gene banks } \\
\text { - Integration with NIAHS/GIAHS for biodiversity enhancement } \\
\text { - Development of protocols for fair and equitable benefit-sharing }\end{array}$ \\
\hline
\end{tabular}

A series of training activities increased the women group's participants from nine elderly women to more than 60 young and aged women plus a few men. In 2012, Guzhai formed the first women-led farmers' professional co-operative, the Rongyan Farmer Cooperative (named after its leader), to start their official business development. Since then, Rongyan Farmer Cooperative has focused on farmer hybrid maize development (a PPB variety, Guinuo 2006, was produced), production of high quality local maize, soybean and chayote shoots. Efforts include the strengthening of technology and marketing aspects and exploring seed registration mechanisms for farmer varieties and PPB seed. Besides maize and soybean experiments, the Rongyan Farmer Cooperative has carried out vegetable variety selection and wild vegetable variety domestication for marketing. In late 2014, the cooperative started to build local marketbased channels, and chayote shoots emerged as a preferred choice to cooperative members. In 2014, the Farmers' Seed
Network organized its first annual meeting in Nanning. The meeting offered a training session on how to use a community seed registry (including photos) to document local varieties to 10 community participants, including from Guzhai village. At the end of 2019, Guzhai community had registered 124 local varieties, including maize (9), bean and pea (11), squash and melon (8), vegetables (24), and wild medicinal plants (53). The cooperative has utilized several local vegetable, maize and Arrowroot (Canna edulis) varieties as its core products. In 2015, the farmers of the cooperative decided to establish a community seed bank, building on the cumulative efforts of PPB, eco-circular farming, Community Supported Agriculture (CSA), community registration of local varieties and participatory variety selection. Since its inception, the Guzhai community seed bank has been working with community seed plots to conduct trials of wild vegetable domestication and Guinuo 2006 hybridization. Plant and wild relative species conserved by the seed bank are: maize 
(seven varieties), bean (9), melon (10), vegetables (25), and medicinal herbs (12). Of the total collection, 37 are traditional varieties including 3 varieties of maize, 5 bean, 7 melon, 17 vegetables and 5 Chinese herbs. News of the seed bank spread by word of mouth as the cooperative members collected vegetables. The varieties in the seed bank are provided to villagers free of charge, registered at the time of use, and doubled back at harvest time. Today there are 89 villagers using the seed bank, 21 of whom are young men and women, and the rest are women over 50 years old. The Farmers' Seed Network regularly visits and monitors the activities of the community seed bank, but day-to-day operations are in the hands of the member farmers.

The Guzhai seed bank is linked to the government germplasm bank. In 2019, GMRI breeders collected three local germplasm resources, namely Mexican white maize, local yellow maize and local glutinous maize, from the Guzhai seed bank and put them into the National Germplasm Bank and the Guangxi Academy of Agricultural Sciences Germplasm Bank for conservation.

\section{Case 2. Valuing Cultural Heritage: the Centenary Granaries of Wangjinzhuang Village, North China}

The second case study focuses on agrobiodiversity enhancement for the dynamic conservation of agricultural heritage. Some seed banks, such as the Wangjinzhuang Farmer Seed Bank, have established systematic conservation mechanism including seed registration, a management charter and a diversity block, contributing to the dynamic conservation of agrobiodiversity and related cultural heritage in remote areas. Compared to the alarming loss of local seed diversity in North China, Wangjinzhuang village still retains many varieties of vegetable, bean, legume and especially millet, the main staple food.

Wangjinzhuang village belongs to Jingdian Town, She County, Handan City, Hebei Province, and is located on the eastern foot of the South Taihang Mountains with steep slopes stretching from 203 to 1,563 m. Relying on the natural climate for planting, villagers have worked out a survival strategy, which they describe as "using the land to plant a hundred kinds of crops and not rely on the sky." Agricultural biodiversity is a living source and key source of support of their agricultural heritage. They sum up the sustainable way of living as follows: "saving seeds by the people, conserving crops in farmers' fields, stocking harvest in farmers' granaries, economizing grain with a gentle appetite.” The Shexian Dryland Terrace System of Wangjinzhuang Village was identified as a China-National Important Agricultural Heritage System (China-NIAHS) in 2014 and nominated to become a Globally Important Agricultural Heritage System (GIAHS) in 2019 as well.

With the abundance of traditional varieties, three She County Dryland Terrace Conservation and Utilization Association (the Terrace Association) members decided to set up a community seed bank. They want to use it as a public space to showcase the achievements of Wanginzhuang villagers in conserving seeds and to remind everyone that "old" seeds are quietly dwindling and everyone needs to work together to pass down the local survival wisdom, strengthen the farmers' seed system and guard the future. The Farmers' Seed Bank of Wangjinzhuang Village was established in November 2019. Its logo reads: "Conserve by fulfilling potentials, Utilize through biocultural inheritance, Multi-stakeholder participation, Dynamic conservation."

Seeds were brought from the granary of households to the community seed bank for display. There are 106 varieties of 10 types of commonly grown crops conserved, all of which are local varieties, of which 82 are traditional varieties. Some traditional varieties have been grown for hundreds of years continuously adapting to changing conditions. All seeds saved in the community seed bank have been registered as collectively owned community resources. The commonly grown crop varieties and traditional varieties are listed in Table 5. Traditional food crops are bolded. Hundred-year-old varieties that are well documented are in bolded italics; and in italics for those that are "characterized" in people's minds. The activities of the community seed bank are guided by the Farmers' Field School (FFS) approach, which is implemented with the guidance of plant breeders. Farmers participate in evaluation and tasting events organized by the FFS, which not only enhances farmers' seed knowledge, but also strengthens community organization to establish close seed exchange and learning relationships with the Community-Supported Agriculture platform and farmers' market and other dryland farming communities.

The number of members for managing the community seed bank has grown from 5 to 43 , with the number of women increasing from 1 to 26 . The community seed bank is open to all villagers and non-member villagers who can use the seeds from the community seed bank with the consent of the Terrace Association. When this community seed bank was first established, the members of Terrace Association discussed management options regarding the community seed bank under the guidance of the Agricultural Bureau of She County, Hebei Province. They drafted “The Management Methods of Farmers' Seed Bank of Wangjinzhuang Village about She County Dryland Terrace System (trial)." Article 4 of these management methods specifies the rules for villagers to use the community seed bank: If the local villagers really need to use seeds from the community seed bank for field planting, they can do so with the approval of the president of the Terrace Association and the full-time custodian. If you take $1.0 \mathrm{~kg}$ seeds from the community seed bank for planting, you need to return $1.5 \mathrm{~kg}$ seeds after harvest. The seeds that are taken away must have a backup in the community seed bank. The farmers contend that it is not difficult to repay what you borrow and thus the seeds of the community seed bank will be constantly flowing, like water.

The villagers expect the seeds in the community seed bank to remain viable so that they can access them when needed. On 1 March 2020, the key members of the Terrace Association discussed and started setting up seed multiplication fields and invited interested villagers to do the same. This will allow selecting plants (seeds) that are well adapted to the 
TABLE 5 | Commonly grown crop varieties and traditional varieties of Wangjinzhuang village.

\begin{tabular}{|c|c|c|}
\hline Crop & $\begin{array}{l}\text { Number of } \\
\text { varieties }\end{array}$ & Variety type/name \\
\hline Maize & 5 & $\begin{array}{l}\text { Golden queen, White horsetooth, Purple maize, Three rough yellow maize, Three rough } \\
\text { white maize }\end{array}$ \\
\hline Millet & 22 & $\begin{array}{l}\text { Lai wuxian, Lou miqing, Pi maqing, Qing gu, Hong miao lao laibai, Little huangcao, Luo } \\
\text { huahuang, Shanxi yichihuang, White seedling mao millet, White seedling red millet, Old millet, } \\
\text { White millet, White seedling millet, Red millet, Yellow millet, Broomcorn millet, Soft millet, Lao } \\
\text { laibai, Maogu, San bianchou, Ya talou, Ma jizui }\end{array}$ \\
\hline Sorghum & 6 & $\begin{array}{l}\text { Red sorghum, Broom sorghum, Tall red sorghum, Qitou sorghum, white sorghum, Shaozhou } \\
\text { sorghum }\end{array}$ \\
\hline Legumes & 25 & $\begin{array}{l}\text { Civet cat small beans, Red small beans, Small white beans, Two black lentils, Small } \\
\text { black-faced green lentils, Little green lentils, Large green lentils, Small soybean, Two soybean, } \\
\text { Red and small soybean, Two little red bean, Little red bean, Little green lentils, Little white bean, } \\
\text { Little red bean, Brown lentil, Small southern beans, Mung bean, Pea, Lima bean, Broad bean, } \\
\text { Cowpea (purple long and green long), Large black lentils, Small black lentils, Small green lentils }\end{array}$ \\
\hline Common bean & 12 & $\begin{array}{l}\text { Black mosi bean, Yellow mosi bean, Bean, Purple bean, Flower skin bean, Green bean, Little } \\
\text { Cai bean, Purple eyebrow bean, Green eyebrow bean, Broad eyebrow bean, Small white } \\
\text { eyebrow bean, Purple wattle eyebrow }\end{array}$ \\
\hline Cucurbits & 12 & $\begin{array}{l}\text { Green pumpkin, Old pumpkin, Local pumpkin, Red pumpkin, Yellow pumpkin, Red and long } \\
\text { Chinese cucumber, Long sponge gourd, Little sponge gourd, Vegetable marrow, Cucumber, } \\
\text { Bottle gourd, Balsam pear }\end{array}$ \\
\hline Fruits and vegetables & 6 & $\begin{array}{l}\text { Chao Tian Jiao (Capsicum annuum var. conoides), Large hot pepper, Large tomato, Little } \\
\text { tomato, Little hot pepper, Long eggplant, Round eggplant, Vegetable pepper }\end{array}$ \\
\hline Tubers & 6 & $\begin{array}{l}\text { Red mustard root, Mustard, Stem mustard, Red/White mustard root, Turnip, Small mustard } \\
\text { root }\end{array}$ \\
\hline Radish & 6 & $\begin{array}{l}\text { Green head old white radish, Purple white radish, Red radish, Whipstick yellow radish, White } \\
\text { radish, Yellow radish }\end{array}$ \\
\hline Oilseeds & 6 & Hemp, Sesame, Peanut, Sunflower, Canola, Perilla \\
\hline
\end{tabular}

current local climate. With continuous selection each year, this living conservation of germplasm resources can also enrich the collective wealth of Wangjinzhuang village. The seed production will be organic-ecological to meet the small-scale seed needs of the village.

\section{Case 3. Yuefengdao: Banking Seeds for Organic Agriculture and a Healthy Diet in the East of China}

The third case study focuses on the access and utilization of local seeds for adding value to seeds and produce. The research reveals that community seed banks can contribute to organic farming by providing diverse seeds. Some seed banks in China have the function of access and utilization, which is often linked to a niche market, providing seeds for agroecological farming or new varieties with specific flavors for consumers. In the context of ecological agriculture, rural communities and smallholder farmers have difficulty in accessing seeds that are organic certified or ecological, and the cost of saving and improving seeds remains high. If a community or eco-farm establishes its own seed bank to save local seeds at low cost, these seeds not only provide an adequate genetic resource for agroecology, but also supply new varieties in an emerging market. Some seed banks have been integrated in community-level initiatives of PPB, PVS, and ecological seed production, further enhancing their vitality. The small-scale, market-driven crop variety improvement practices have revived some varieties that were previously abandoned by farmers, allowing them to be reintroduced and regenerated under new conditions. The same varieties are often neglected by public institutes and commercial seed companies, which can be seen as a shortcoming or a missed opportunity or both.

Yuefengdao Organic Farm is located west of Kunshan City and close to the Yangcheng Lake, Jiangsu province, covering an area of 13 hectares. The farm is situated in a wetland reserve and has been operating organic farming since 2010. Kunshan used to be an important rice cultural region with a long history of paddy culture. 6,000-year-old carbonized rice seed was unearthed in Chuodunshan village, which is located only $1 \mathrm{~km}$ away from the farm. After 40 years of rapid economic development, Kunshan has become one of the most developed counties in China, but the current agriculture model of largescale activities and high use of chemical inputs has led to depletion of natural resources and environmental pollution. Traditional farming practices were on the verge of disappearing. Around 2010, remarkable changes started to take place due to a policy shift and market transformation. In the city, the growing middle-income class emerged as critical consumers demanding healthy food. At the same time, the local government put great effort in conserving the wetlands around the Yangcheng Lake and adopted environment-friendly agriculture as solution to mitigate the deteriorating environment. 
Since 2014, Yuefengdao Organic Farm cooperated with local communities to produce organic rice to demonstrate its commitment to support local farmers to practice agroecology together with their traditional practices and a revitalized seed system. One of the problems farmers faced was that many rice and most vegetable seeds were only available on the market, but with unknown quality and traceability, while they had lost traditional varieties and seed saving practices. In 2015, Yuefengdao and Farmers' Seed Network organized a baseline survey of the local seed system. This survey revealed that the rice landraces had almost disappeared while the dominant cultivars, in particular Nanjing 46, were promoted by local agricultural research institutes, extension agents and seed companies. The survey also revealed that the eight famous aquatic vegetables, including Manchurian wild rice, arrowhead, water caltrop, watershield, gorgon fruit, water chestnut, lotus root, and water fennel, are important in local food culture, but at risk of extinction due to the habitat loss. On the positive side, the survey indicated that farmers still conserve a few soybean landraces as part of the seasonal diets.

To address the troubling local seed supply situation, in 2017, Yuefengdao Organic Farm set up a seed bank to save the most important varieties and landraces collected in the communities. Three types of crops are saved in the seed bank, including rice, vegetables and endangered local crops. The seed bank has the function of access and utilization of seed providing for organic farming to meet market demand and consumer preferences. Another function of the seed bank is to save crops with local characteristics, such as aquatic vegetables and taro, for future utilization. The seed bank is currently managed by three highly qualified farm staff who are familiar with local varieties and have rich farming experiences. Regeneration of the varieties in turn contributes to the transmission of local farming knowledge. Other activities include participatory soybean varieties selection, community agrobiodiversity registration and a diversity block. With regard to the vegetables and rice with market value, the farm grows 13 types and 105 crop varieties each year, of which vegetables account for $80 \%$. The farm saves seed of 13 vegetables (including four specialty crops) in the community seed bank based on the criteria of technical feasible, good taste and high quality (Table 6). In 2016, the farm set up a diversity block of 25 rice varieties to test their adaptability; six were selected for production, including three of which seed are stored in the seed bank.

Among the rice varieties, Suyunuo stands out. It is a local sticky rice variety with special color, aroma and taste. In 2015, the farm obtained a small amount of rice seed from the genebank of the Jiangsu Academy of Agricultural Sciences to examine the local adaptability and market response of this "lost" variety. It proved quite difficult to plant, breed and promote Suyunuo after it had been abandoned for more than two decades (Table 7). The changing ecology and climate in the area require technical knowhow to re-adapt the variety. After 5 years of planting, Suyunuo still has a short growing period, poor pest resistance and high incidence of lodging, resulting in yield loss. On the consumer end, this "lost" variety needs time to reappear on the table. Currently, the local agricultural extensionists are interested
TABLE 6 | Crops/varieties conserved in the Kunshan seed bank (2020).

\begin{tabular}{|c|c|c|}
\hline \multicolumn{2}{|l|}{ Crop/variety } & Amount of seed $(\mathrm{kg})$ \\
\hline \multicolumn{2}{|l|}{ Suyunuo sticky rice } & 50 \\
\hline \multicolumn{2}{|l|}{ Yaxuenuo sticky rice } & 35 \\
\hline \multicolumn{2}{|l|}{ Black rice } & 25 \\
\hline \multicolumn{2}{|l|}{ Potato } & 150 \\
\hline \multicolumn{2}{|l|}{ Sesame } & 2 \\
\hline \multicolumn{2}{|l|}{ Garlic } & 30 \\
\hline \multicolumn{2}{|l|}{ Black bean } & 2 \\
\hline \multicolumn{2}{|l|}{ Mung bean } & 1 \\
\hline \multicolumn{2}{|l|}{ Red bean } & 1 \\
\hline \multicolumn{2}{|l|}{ Broad bean } & 15 \\
\hline \multicolumn{2}{|l|}{ Soybean } & 5 \\
\hline \multicolumn{2}{|l|}{ Taro } & 150 \\
\hline Area $(\mathrm{mu})^{*}$ & Production (kg) & Note \\
\hline 2017 & 4,500 & \\
\hline 2018 & 200 & \\
\hline 2019 & 0 & Not grown this year \\
\hline 2020 & Not yet known & \\
\hline
\end{tabular}

*1 mu,0.067 ha.

in the regeneration of Suyunuo and willing to work with the farm to improve it. The case of Suyunuo demonstrates that organic farms can benefit greatly from support by public research institutes, in particular when repatriating seed from the genebank to farmers' fields.

\section{DISCUSSION AND PROSPECTS}

This succinct review of community seed banks in China and the detailed description of three cases, points to the utility and viability of this form of farmer organization in the country, in particular when supported by research and extension. In a relatively short period of time, community seed banks with varied functions have been established in different parts of the country, responding to particular local histories, needs and interests, and research and development trajectories. Community seed banks are good examples of how Chinese farmers' and their communities continue to contribute to the maintenance and improvement of genetic resources. They are also a practical mechanism to recognize and gain respect and support for farmers' rights in terms of research, policy and law. The multiple functions and services of community seed banks, and the efforts made by smallholder farmers who manage them, should be at the heart of China's conservation of agricultural biodiversity policymaking.

The three cases demonstrate the diversity and versatility of community seed banking "the Chinese way." The Guzhai case shows the multiple functions of a community seed 
bank, including as a platform for rural development. The Wangjinzhuang Farmer Seed Bank is an example of a specialized community seed bank, building on a long history of seed saving, but responsive to the demands of modern time. The Yuefengdao Organic Farm demonstrates how diversified organic conservation and seed production can successfully be combined to create an enterprise that caters to the growing market of healthy and nutritious food. Community seed banks can benefit greatly from technical support, in particular during the startup period, such as provided by the Farmers' Seed Network. The organization of collaborative activities, such as training, participatory crop experimentation and seed/food fairs, can contribute to sustainability.

Perhaps surprisingly, the review also reveals that the China experience does not only offer rich empirical evidence, but does make an important contribution to theory as well. The two newly identified functions, adding value to seed and produce and seed systems linkages and collaboration, and several new services, make the conceptual framework more robust. The revised framework will be useful for initiatives to establish new community seed banks, offering a pathway that can lead to more sustainable community seed banks by embedding them (more) firmly in the larger agro-economic and institutional systems. It is important step forward given that (lack of) sustainability has been one of the major challenges (Vernooy et al., 2015).

It is evident that community seed banks can not only conserve seed (including of "lost" varieties), but also provide smallholder farmers and organic farms with low-cost and high-quality seed of various crop types. However, currently, in China they face two challenges: (1) keeping seeds healthy and qualified for inspection and quarantine; (2) having effective participation and management mechanisms. Both challenges can be addressed by offering targeted technical and managerial training. The Farmers' Seed Network will utilize the translated Farmers Handbook to provide training for seed bank members across the country to improve these skills.

The main findings of the China Seed Policy assessment jointly conducted by the Chinese Academy of Sciences, the Farmers' Seed Network and other institutions, present three major farming models in China: the smallholder farming model in the Southwest, the emerging organic farming model in the east, and the industrial farming model in the north (Farmers' Seed Network China [FSN]., 2019). Under different agroecological conditions, the five community seed bank functions should be tailored to local farming models and development paths and supported by appropriate policies. Scientists from IEMPUNEP and KIB of the Chinese Academy of Sciences working with the Farmers' Seed Network have drafted a policy brief submitted to the Academy on "Building Government-led, Multistakeholder Participation and Benefit Sharing Mechanisms in Crop Genetic Resource Conservation and Healthy Development of the Farmers' Seed Systems." In this policy recommendation, two of five suggestions are related to community seed banks. These are:

1. To establish a mechanism for backup and genetic resource sharing between national and local germplasm banks and farmers' seed systems to effectively protect and utilize the resources of our traditional crop varieties and farmers' varieties.

a After the community systematically identifies and collects traditional crop varieties, establish community seed banks (short-term) to standardize the seed storage and management system.

b Conserve community germplasm resources in national and local medium- and long-term genebanks, with mutual backup and access and benefit-sharing mechanisms with the national conservation system.

c Make full use of the resources of national and local community seed banks to carry out participatory field evaluation, improvement and variety selection.

2. Use the internationally accepted system of access and benefitsharing of genetic resources, as regulated by the International Treaty on Plant Genetic Resources for Food and Agriculture (ITPGRFA) and the Nagoya Protocol on Access to Genetic Resources and the Fair and Equitable Sharing of Benefits Arising from their Utilization to the Convention on Biological Diversity, and national regulations on the protection of geographical indications to explore new community seed banks benefit-sharing mechanisms, protect and motivate farmers to participate in seed selection and conservation.

The Farmers' Seed Network has an important role to play to advance the community seed bank agenda in China. This will be done through active participation in international collaborative networks, increased knowledge exchanges and promotion of the common development of plant genetic resources through the South-South cooperation framework. The Farmers' Seed Network is also promoting the "From Seed to Table" initiative, which started in 2018, to link community seed banks to other stakeholders, thus linking producers to consumers directly, encouraging interaction and exchanges, thus building up a living seed system and resilient food system.

\section{DATA AVAILABILITY STATEMENT}

The raw data supporting the conclusions of this article will be made available by the authors, without undue reservation.

\section{ETHICS STATEMENT}

Ethical review and approval was not required for the study on human participants in accordance with the local legislation and institutional requirements. Written informed consent for participation was not required for this study in accordance with the national legislation and the institutional requirements.

\section{AUTHOR CONTRIBUTIONS}

RV and YS: development of methodology. XS and GL: field research. XS, GL, RV, and YS: data analysis and manuscript. RV: review and editing. YS: fundraising. All authors contributed to the article and approved the submitted version. 


\section{FUNDING}

The work on community seed banks has benefitted from the financial support of Oxfam Hong Kong (Beijing office) and Brot für die Welt.

\section{ACKNOWLEDGMENTS}

We acknowledge the valuable collaboration of the members of the community seed banks included in the study and

\section{REFERENCES}

Andersen, R., Shrestha, P., Otieno, G., Nishikawa, Y., Kasasa, P., and Mushita, A. (2018). Community Seed Banks-Sharing Experiences from North and SOUTH. Paris, DIVERSIFOOD. Available online at: https://www.fni.no/ publications/community-seed-banks-sharing-experiences-from-north-andsouth (accessed November 16, 2020).

Bellon, M. R., Mastretta-Yanes, M., Ponce-Mendoza, A., Ortiz-Santamaría, D., Oliveros-Galindo, D., Perales, H.,et al. (2018). Evolutionary and food supply implications of ongoing maize domestication by Mexican campesinos. Proc. $R$. Soc. B 285:20181049. doi: 10.1098/rspb.2018.1049

Center for Chinese Agricultrual Policy [CCAP]. (2018). An Impact Assessment of China's Seed Policy. A working policy paper by a research team of multidisciplines scientists from different institutions, coordinated by CCAP and FSN. Beijing: CCAP.

Development Fund (2011). Banking for the Future: Savings, Security and Seeds. A Short Study Of Community Seed Banks in Bangladesh, Costa Rica, Ethiopia, Honduras, India, Nepal, Thailand, Zambia and Zimbabwe. Oslo: Development Fund. Available online at: https://www.utviklingsfondet.no/files/uf/documents/ Rapporter/Banking_for_the_future.pdf (accessed November 16, 2020).

Farmers' Seed Network China [FSN]. (2019). Sowing Diversity Harvesting Security Sustaining Future. An Impact Assessment of China's Seed Policy. Beijing: FSN. Available online at: https://www.oxfam.org.cn/index.php?c=articleandid $=4042$ (accessed November 16, 2020).

Food and Agricultural Organization of the United Nations [FAO]. (2008). Country Report on the State of Plant Genetic Resources for Food and Agriculture: China. Rome: FAO.

Gao, D., He, X., and Zhu, Y. (2011). Changes of rice landraces diversity and rules of seed exchange in Yuangyang of Yunnan. J. Plant Gene. Resour. 12, 311-313. Available online at: https://www.ingentaconnect.com/content/jpgr/jpgr/2011/ 00000012/00000002/art00024 (accessed November 16, 2020).

He, X. H., Zhu, S. S., Wang, H. N., Xie, Y., Sun, Y., Gao, D., et al. (2010). Crop diversity for ecological disease control in potato and maize. J. Resour. Ecol. 1, 45-50. doi: 10.3969/j.issn.1674-764x.2010.01.006

Intergovernmental Science-Policy Platform on Biodiversity and Ecosystem Services [IPBES]. (2019). Global Assessment Report on Biodiversity and Ecosystem Services. Bonn: IPBES. Available online at: https://ipbes.net/globalassessment (accessed November 16, 2020).

Joshi, B. K., Shrestha, P., Gauchan, D., and Vernooy, R. (eds.). (2018). “Community seed banks in Nepal," in 2nd National Workshop Proceedings, 3-5 May 2018 (Kathmandu: NAGRC, LI-BIRD and Bioversity International). Available online at: https://hdl.handle.net/10568/99141 (accessed November 16, 2020).

Li, C., He, X., Zhu, S., Zhou, H., Wang, Y., Li, Y., et al. (2009). Crop diversity for yield increase. PLoS ONE 4:p.e8049. doi: 10.1371/journal.pone.0008049

Li, J., Lammerts van Bueren, E., Jiggins, J., and Leeuwis, C. (2012). Farmers' adoption of maiz (Zea mays L.) hybrids and the persistence of landraces in Southwest China: implications for policy and breeding. Gene. Resour. Crop Evol. 59, 1147-1160. doi: 10.1007/s10722-011-9750-1

McGuire, S., and Sperling, L. (2013). Making seed systems more resilient to stress. Glob. Environ. Change 23, 644-653. doi: 10.1016/j.gloenvcha.2013.02.001

Mijatović, D., Van Oudenhoven, F., Eyzaguirre, P., and Hodgkin, T. (2013). The role of agricultural biodiversity in strengthening resilience to climate change: towards an analytical framework. Int. J. Agric. Sustain. 11, 95-107. doi: 10.1080/14735903.2012.691221 the inputs provided by our colleagues from the supporting institutions involved.

\section{SUPPLEMENTARY MATERIAL}

The Supplementary Material for this article can be found online at: https://www.frontiersin.org/articles/10.3389/fsufs. 2021.630400/full\#supplementary-material

Ministry of Agriculture and Rural Affairs (2020). Open a New Chapter in the Conservation and Utilization of Agricultural Germplasm Resources: The Interpretation of the Opinions on Strengthening the Conservation and Utilization of Agricultural Germplasm Resources of the State Council from the Head of Ministry of Agriculture and Rural Affairs. February 11, 2020. Available online at: http://www.moa.gov.cn/xw/zwdt/202002/t20200211_6336906.html (accessed November 16, 2020).

National Bureau of Statistics [NBS]. (2017). Main Data Bulletin of the Third National Agricultural Census (No. 1). Beijing: NBS. Available online at: http:// www.stats.gov.cn/tjsj/tjgb/nypcgb/qgnypcgb/201712/t20171214_1562740.html (accessed November 16, 2020).

Porcuna-Ferrer, A., Fiala, V., Freyer, B., van Etten, J., Vernooy, R., and Probst, L. (2020). Do community seed banks contribute to the socialecological resilience of communities? A case-study from western Guatemala. Int. J. Agric. Sustain. 18, 232-249. doi: 10.1080/14735903.2020. 1747199

Shrestha, P., Clancy, E., and Vernooy, R. (2020). A Level Up: Community Seed Banks in Nepal Join Forces. Rome: Bioversity International, Rome; Pokhara: LI-BIRD. Available online at: https://hdl.handle.net/10568/108049 (accessed November 16, 2020).

Song, Y. (1998). 'New' Seeds in 'Old' China: Impact Study of CIMMYT's Collaborative Programme on Maize Breeding in Southwest China (Ph.D. thesis),Wageningen University and Research Centre, Wageningen. Available online at: https://edepot.wur.nl/136399 (accessed November 16, 2020).

Song, Y., Vernooy, R. (2010). Seeds of empowerment: action research in the context of the feminization of agriculture in Southwest China. Gender Technol. Dev. 14, 25-44. doi: 10.1177/09718524100 1400102

Song, Y., Vernooy, R., Qi, L., Xie, H., Tian, M., Song, X. (2019). “A 20-year journey," in Participatory Plant Breeding of Maize in SouthWest China, in Farmers and Plant Breeding. Current Approaches and Perspectives, eds O. Westengen and T. Winge (London: Routledge), 119-134. doi: 10.4324/9780429507335-9

Subedi, A., and Vernooy, R. (2019). "Healthy food systems require resilient seed systems," in Agrobiodiversity Index Report 2019: Risk and Resilience, ed Bioversity International (Rome: Bioversity International), 127-134. Available online at: https://hdl.handle.net/10568/100820 (accessed November 16, 2020).

The State Council of The People's Republic of China (2020). "Agricultural Germplasm Resources to Be Protected, Utilized.” February 11, 2020.

Vernooy, R. (2003). Seeds That Give. Participatory Plant Breeding. Ottawa: International Development Research Centre. Available online at: https://www. idrc.ca/en/book/infocus-seeds-give-participatory-plant-breeding (accessed November 16, 2020).

Vernooy, R., Bessette, G., and Otieno, G. (eds.). (2019a). Resilient Seed Systems: Handbook, 2nd Edn. Rome: Bioversity International. Available online at: https://hdl.handle.net/10568/103498

Vernooy, R., Bessette, G., Sthapit, B., Dibiloane, A., Lettie Maluleke, N., Abner Matelele, L., et al. (2020a). How to Develop and Manage Your Own Community Seed Bank: Farmers' Handbook (Updated Version). Establishing a Community Seed Bank: Booklet 1 of 3. Rome: Bioversity International. Available online at: https://hdl.handle.net/10568/92000

Vernooy, R., Bessette, G., Sthapit, B., and Gupta, A. (2020b). How to Develop and Manage Your Own Community Seed Bank Farmers' Handbook (Updated 
Version). Technical Issues: Booklet 2 of 3. Rome: Bioversity International. Available online at: https://hdl.handle.net/10568/92001 (accessed November 16, 2020).

Vernooy, R., Bessette, G., Sthapit, B., and Porcuna Ferrer, A. (2020c). How to Develop and Manage Your Own Community Seed Bank: Farmers' Handbook (Updated Version). Management, Networking, Policies and a Final Checklist: Booklet 3 of 3. Rome: Bioversity International. Available online at: https://hdl. handle.net/10568/92002 (accessed November 16, 2020).

Vernooy, R., Clancy, E., Diulgheroff, S., Furman, B., González Santos, R., Guarino, L., et al. (2018). Joining Forces to Strengthen Community Seedbanks Worldwide. Rome: Bioversity International. Available online at: https://www. bioversityinternational.org/fileadmin/user_upload/Joining_Vernooy_2018.pdf (accessed November 16, 2020).

Vernooy, R., Matelele, L. A., Sema, R. P., Mokoena, M. P., Maluleke, N. L., Tjikana, T., et al. (2019b). Green Shoots. Community Seed Banking in South Africa: Endeavours and Outcomes 2016-2019. Rome: Bioversity International; Pretoria: Department of Agriculture, Forestry and Fisheries. Available online at: https:// cgspace.cgiar.org/handle/10568/101495 (accessed November 16, 2020).

Vernooy, R., Shrestha, P., and Sthapit, B. (eds.). (2015). Community Seed Banks: Origins, Evolution and Prospects. London: Routledge. doi: 10.4324/9781315886329

Vernooy, R., Sthapit, B., Galluzzi, G., and Shrestha, P. (2014). The multiple functions and services of community seed banks. Resources 3, 636-656. doi: 10.3390/resources3040636

Vernooy, R., Sthapit, B., Otieno, G., Shrestha, P., and Gupta, A. (2017). The roles of community seed banks in climate change adaption. Dev. Pract. 27, 316-327. doi: 10.1080/09614524.2017.1294653
Vernooy,. R., Song, Y., Zhang, Z., Li, J., Liu, L., Martins, C., et al. (2013). Developing an agricultural biodiversity policy for China. Agroecol. Sustain. Food Syst. 37, 1078-1095. doi: 10.1080/21683565.2013.800627

Xinhua News (2018). "China is facing the dilemma of seed conservation." October 9, 2018. Available online at: http://www.xinhuanet.com/fortune/2018-10/09/c 1123530826.html (accessed November 16, 2020).

Xinhua News (2019). "National Bank of Crop Germplasm Resources to be built in March with capacity of 1.5 million accessions.” January 17, 2019. Available online at: http://www.xinhuanet.com/politics/2019-01/17/c_1124000762.html (accessed November 16, 2020).

Yang, Y., Zhang, E., Jarvis, D.I., Bai, K., Dong, C. A. Xinxiang, Tang, C., et al. (2015). "China: the Xiding gene bank in Yunnan," in Community Seed Banks: Origins, Evolution and Prospects, eds R. Vernooy, P. Shrestha and B. Sthapit (London: Routledge), 94-98.

Zhu, Y. Y. (2010). Crop diversity for ecological disease control in potato and maize. J. Resour. Ecol. 1, 1-9.

Conflict of Interest: The authors declare that the research was conducted in the absence of any commercial or financial relationships that could be construed as a potential conflict of interest.

Copyright (c) 2021 Song, Li, Vernooy and Song. This is an open-access article distributed under the terms of the Creative Commons Attribution License (CC BY). The use, distribution or reproduction in other forums is permitted, provided the original author(s) and the copyright owner(s) are credited and that the original publication in this journal is cited, in accordance with accepted academic practice. No use, distribution or reproduction is permitted which does not comply with these terms. 